\title{
Financial Management a Wheel to Financial Performance of Local Governments in Uganda: A Case Study of Tororo Municipal Council
}

Tomasi Mutya* and Akumu Josephine

Department of Business Studies, Kumi University, Uganda

\begin{abstract}
This study sought to establish "the Effects of Financial Management on Financial Performance" and special emphasis was put on Tororo Municipal Council Local Government as the context of study. The major purpose was to bridge a gap, generate new ideas and validate other researchers' findings by examining the effects of financial management on financial performance. This study was conducted through the use of a descriptive design. The target population of this study was 33 finance staff of TMC from which 30 were selected using random and purposive sampling technique. This study made use of questionnaires for primary data collection. It explored the benefits of budgetary management on $F / P$, role of planning on financial performance and relationship between financial management and financial performance of TMC LG. The findings included the following: Findings on the relationship between F/M and F/P at TMC LG. The findings showed a positive relationship of 0.91 between the variables. This means that there is a strong financial management system in TMC LG which leads to increased level of financial performance. The researcher recommended that the management of TMC LG to frequently revisit their budget activities to ensure that there is no deviation from the budget and expenditures.
\end{abstract}

Keywords: Financial management; Financial performance; Budgetary management and planning

Acronyms: TLD:TororoLocalGovernment;TMC:Tororo Municipal Council; F/M: Financial Management; F/P: Financial Performance; LC: Local Council; DV: Dependent Variable; ID: Independent Variables; UCU: Uganda Christian University; GPRA: Government Projects and Resource Allocations; LG: Local Government; COSA: Cornerstone Old Students Association; PAF: Poverty Alleviation Fund; IFMS: Integrated Financial Management System; ACODE: Advocate Coalition for Development and Environment; BMAU: Budget Monitoring and Accountability Unit; FY: Financial Year; NDP: National Development Plan; LGSCA: Local Government Scorecard Assessment; MFPED: Ministry of Finance, Planning and Economic Development; CAO: Chief Administrative Officer; RDC: Resident District Commissioner; NPPAS: National Priority Program Areas.

\section{Introduction}

The rapidly changing nature of today's external environment continuously creates a need for business strategy, process improvements and organizational transformation to ensure survival in today's highly competitive market. Today, businesses globally are under constant pressure to develop, implement and rapidly revise their financial management strategies. To do this, businesses and organizations need to develop and implement financial strategies to manage risk and improve $\mathrm{F} / \mathrm{P}$ and capabilities as depicted in the resource based theory [1].

The financial management of local governments are generally dominated by conditions of financial resource scarcity since they are nonprofit organizations and have limited opportunities for generating funds but are faced with ever increasing agenda of programs and activities on which such funds could be spent. However, F/P can be improved through raising and allocation of financial resources, planning and controlling these resources to attain the stated goals in a broad sense. In a narrow sense, financial management is a routine function which are performed within the firm to ensure efficient use of funds. In order to achieve its goals of timely service delivery and proper accountability among others, the government of Uganda initiated the implementation of IFMS in April 2015 in all local governments in the country. The IFMS aimed at promotion of efficiency, effectiveness, accountability and transparency and comprehensive financial reporting. The functionality of IFMS varies between ministries, agencies, departments and local governments. This program is currently used by 23 local governments and TMC is inclusive. This has led to improvement in financial management as accountability has improved in terms of timeliness and accuracy from $47 \%$ to $50 \%$ over the period as indicated by Budget Monitoring and Accountability Unit (BMAU) of ministry of Finance, Planning and Economic Development with support from the DANIDA under the support to Budget monitoring and Accountability project.

According to the Public Finance Management Act 2015, Local Government have continuously carried out financial management through drawing up financial year budgets that show estimated revenue and expenditures but sometimes there have been some short falls in the proper management and financial performance in this local government. This is because the Government does not transfer the exact figures budgeted for and tax payers for local revenue avoid taxes thereby the council collects less than what is budgeted for. It is upon this back ground that planning and budgeting become one of the functions of the district council. Under these parameters, availability and approval of plans, vision, mission statements and levels of revenue collection is focused on since local governments in Uganda are non-profit organizations. Local revenue is important for ensuring local Government discretion with regard to setting local priorities. Therefore, the more local revenue TMC collects, the more capacity and flexibility it has to respond to service delivery issues raised by the voters.

${ }^{*}$ Corresponding author: Tomasi Mutya, Department of Business Studies, Kumi University, Uganda, Tel: +256754251171; E-mail: mutyatomasi@gmail.com

Received June 01, 2018; Accepted June 28, 2018; Published June 30, 2018

Citation: Mutya T, Josephine A (2018) Financial Management a Wheel to Financial Performance of Local Governments in Uganda: A Case Study of Tororo Municipal Council. J Bus Fin Aff 7: 330. doi: 10.4172/2167-0234.1000330

Copyright: ( $) 2018$ Mutya T, et al. This is an open-access article distributed under the terms of the Creative Commons Attribution License, which permits unrestricted use, distribution, and reproduction in any medium, provided the original author and source are credited. 
Local Government Financial and Accounting regulations, 2007 section 78(2) states "that these regulations shall apply to all financial transactions and business of all Local Government councils and administrative units and to the management of all public moneys and public property in local governments, these regulations prevails where there are conflicts between these regulations and any earlier regulations, instructions or circular. Therefore, accounting and financial management of TMC is defined by this Act". According to ACODE policy research series, NO. 70 2015, Tororo district council emerged the best performer with a score of $87 / 100$ score points. This is because; this performance represents an improvement margin in performance of $26 \%$ in FY $2014 / 15$ which is synonymous with the upward trend since FY 2011/12 thus the highest score ever achieved by district council.

\section{Problem statement}

Financial management in LGs is concerned with ensuring funds are available when needed and that they are obtained and used in the most efficient and effective way to benefit the citizens [2]. This was enforced by MFPED through Financial and Accounting Regulations, 2007 and Accounting Manual, 2015 to help local governments and all entities to ably raise and allocate financial resources to various planned activities so as to promote effective, efficient and timely service delivery to the public, ensure proper accountability in organizations and ensure effective assessment through the scorecard initiative at the end of the financial year.

With the introduction of IFMS in April 2015, processing payments was streamlined and made faster, allocation and control of financial resources was simplified since budgets were drawn and submitted to line managers on time and work plans were adhered and financial records were well monitored by the qualified staff of TMC which fastened service delivery to the public which enabled TMC emerge the best as ranked by Advocate Coalition for Development and Environment (ACODE) policy research series, NO. 70, 2015 this ensures LG scorecard assessment.

However, the situation in TMC local government is still poor accountability with a score of $1 / 3$ according to budgeting and planning scorecard initiative used for LG accountability due to unfavorable allocation, misappropriation, mismanagement and diversion of financial resources as evidenced in the statement of income and expenditure for three FYs $(2011 / 12,2013 / 14 \& 2014 / 15$ (3\%, 8\% \& $26 \%)$ respectively. Much as there is an upward trend in performance, it is still below the average hence poor accountability and delays in service delivery to the community. It is upon this background that the researcher thought of finding out how the above problems lead to poor performance and eventually poor accountability TDLG (Figure 1).

Financial management consists of budgeting, planning and controlling financial resources held by the organization. These influence

\begin{tabular}{|l|l|}
\multicolumn{1}{c|}{$\begin{array}{c}\text { Independent Variable IV } \\
\text { Financial Management }\end{array}$} & \multicolumn{1}{c|}{$\begin{array}{l}\text { Dependent variable } \\
\text { Financial performance }\end{array}$} \\
\hline \begin{tabular}{l|l} 
Budgets \\
Planning \\
Controlling financial \\
resources
\end{tabular} & $\begin{array}{l}\text { Accountability } \\
\text { Financial records } \\
\text { Qualification of the staff } \\
\text { Amount of revenue } \\
\text { available }\end{array}$ \\
\hline
\end{tabular}

Source: Researcher's conceptualization (2018).

Figure 1: Conceptual Frame work. the financial performance through accountability of financial resources of the organization. There are various budgets prepared to assist the planning unit and finance sector in the allocation of financial resources, establish various sources of revenue and in the preparation of financial statements which show how the organization is operating, its financial position and the inflow and outflow of cash in the organization. They also look at resources held by the organization both financial and nonfinancial.

\section{Literature Review}

\section{Finance performance}

According to Stoner, performance refers to the ability to operate efficiently, profitably to survive, grow and react to the environmental opportunities and threats. In agreement with this, Sollenberg and Anderson assert that, Performance is measured by how efficient the enterprise is using its resources in achieving its objective. It is the measure of attainment achieved by an individual team, organization or process (EFQ M 1999). Rawood Academy of management journal 1984-adm-org. added that financial performance is a means of measuring the results of a firm's policies and operations in monetary terms. It is an important element of local government modernization as attained in the fifth national social Partnership agreement program for prosperity and fairness.

Financial performance is defined as a subjective measure of how well a firm can use its assets from its primary mode of business and generate revenues. Furthermore, this term is used as a general measure of a firm's overall financial state over a given period of time and can be used to compare similar firms across the same industry.

Hohler [3], noted that appropriate performance measures are those which enable the organizations to direct their actions towards achieving their strategic objective. Kotey and Meredith contends that, performance is measured by either subjective or objective criteria, arguments for subjective measures includes difficulties with collecting qualitative performance data from small firms with reliability of such data arising from differences in accounting methods used by organizations.

In conclusion therefore, the success of an organization and other companies has historically known to be dependent on the owners and members who undertake the necessary tasks like budgeting to accomplish the set goals and objectives. For the purpose of this study, we will adopt Stonner's definition of financial performance as the ability to operate efficiently, profitability to survive growth and react to the environmental opportunities and threats.

\section{Budgetary management on financial performance}

Budgets occupy a leading place among the tools of management employed to direct and control the affairs of both large and small organizations. A budget is a basic tool in financial management. In this regard it serves as a tool for planning and controlling scarce financial resources in the accomplishment of organizational goals. The budget is an invaluable aid in planning, resource allocation and formulating policy and in keeping check on its execution Premchand. It stipulates which activities and programs should be actively pursued, emphasized or ignored in the period under scope, considering the limited financial resources available to the organization. According to Scarlett [4], budgetary management refers to the principles, procedures and practices of achieving given objectives through budgets. The sound budgetary management system helps in fixing 
the goals of the organization as whole and concerted economies in the enterprise. However, Wagacha notes that any good budgetary management needs to attain three important objectives, namely; maintenance of fiscal discipline, attaining allocative efficiency and operational efficiency.

Other budgetary benefits as indicated by Preetabh [5], include; specific time aims, the plans, policies and goals are decided by the top management. All efforts are put together to reach the common goal of the organization. Every department is given a target to be achieved. The efforts are directed towards achieving some specific aims. If there is no definite aim, then the effort will be wasted in pursuing different aims. As a tool for measuring performance, budgetary management provide comparisons between the budget and targets and actual targets and deviation determined; performance of each department is reported to top management by preparing monthly, quarterly and end of year reports. Margah [6] asserted that that budgetary management is important tool for a country's economy. This is because it allows planning for expenditures thus facilitating systematic spending and allocation of financial resources. Finances are put into optimum use, extending the benefits to industry and national economy. This reduces wastage of national resources.

According to Otley [7], he noted various benefits of budgetary control which includes; helping managers integrate personnel efforts within the organization towards a common goal. This is through appropriating adequate budgets to different activities within the organization and all efforts can be coordinated to achieve organizational objectives. He further added that budgetary control acts as devise to correct any deviations. For instance, if the expenditures for a given activity exceed the allocated budget at any point in time, this will signal a deviation from prescribed course, requiring attention hence maintaining proper financial performance. In addition, budgetary control promotes communication throughout the organizations. This is because prepared budgets are blue prints for organization's plans of operation and can only be coordinated through communication at all levels so as to reduce failure in $\mathrm{F} / \mathrm{P}$ and misunderstandings through transparency and efficiency in the organizations. According to lexjustis. com/wp/wpcontent/uploads/2013/01/solutionsturnkey.jpg, budgetary control helps in measurement of performance. Due to qualification of budgets, the measurement of performance becomes more objective in nature thus eliminating biases that might be introduced due to subjective evaluation.

In conclusion therefore, Scarllet and Preetabh note that budgetary management deals with controlling and allocating financial resources to maximize profits through planning and coordination organizational activities to attain organizational goals through efficient performance and timely accountability among others [4,5].

\section{Planning and financial performance}

Planning as part of the management function involves a long-range planning, strategic planning and short term planning. Lewis, 1996; Stoner, 1996, through information system emphasizes that planning involves selecting objectives and courses of action to achieve them [8]. It is forecasting future milestone or looking ahead and preparing for it through budgeting which leads to efficiency in performance of financial resources. By carrying out planning, the organization is able to assess where it is supposed to be in terms of goals and objectives. However, Bhatia and Chandan noted that sound planning is characterized by clear objectives and goals. It must be simple and well balanced, flexible so to accept any changes in the resources and should be time bound. Effective planning tells when, what and how something is to be done. In order to carryout $\mathrm{F} / \mathrm{M}$, it is necessary to formulate a fully co-ordinate detailed plan in both financial and quantitative terms for the forthcoming period. The time frame is usually one year. The long term development strategy of the organization needs to be in line with the drawn plan.

The planning process ensures that managers do plan for the future operations and consider changes in the next year and what steps they should take to respond to these changes. Briston noted that financial control and monitoring ensures efficient and cost effective program implementation within a system of accountability. However, he notes that the existing financial control arrangements must be complemented by further improvements in overall program monitoring for better budget implementation in accordance with the approved work plans. Therefore, in order to achieve the expected output results through planning, Carr [9] urges that monitoring and evaluation of these results is necessary because it maintains stability under competitions hence important for the effectiveness of local governments.

Lucy noted that establishing planned performance ensures the monitoring of organization's performance. Monitoring actual revenue or cost data is done by way of continuous comparisons of actual performance with budgeted performance. Planning is therefore is the key to success in business since it involves budgeting. Poor budget planning leads to poor performance in organizations. Therefore, planning process enables managers to anticipate problems before they arise and avoid difficult decisions.

Frank and Sangster [10], the planning process ensures that managers do plan for future operations and consider how conditions in the next year might change and what steps they should take to respond to these conditions. He further noted that budgets are put in place in advance based on the anticipated set of circumstances or environment. The major decisions are made based on the long term planning process [11]. However, the annual budgeting process leads to refinement of those plans, since the managers have to produce detailed plans for the implementation of the long range plans.

Financial planning is an essential tool, whether in paper or computerized form Atkinson [12]. These worksheets enable project team members to identify all the major activities required to complete the project, as well as identifying the specific person responsible for ensuring that the activity is completed successfully, the estimated actual work time (e.g. number of work hours/days) and elapse time (e.g. period of days over which the work will take place since staff do not spend all their time on just one activity-they work on several activities or projects concurrently), and the financial and material or other resources required for that activity Bonner and Sprinkle. Once all major activities are identified in this manner, the detailed planning charts can be completed by breaking down each major activity into its various tasks Burchell. Note that each activity and task has its unique number to prevent any confusion in project discussions on the work to be performed. Also, this tool specifies the individual accountable for each activity.

In conclusion therefore, planning is the key to the success of any organization or business since it enables managers to forecast the future and prepare for any changes or conditions. It also ensures monitoring, controlling and evaluation of various activities as reviewed by the previous scholars. 


\section{Relationship between financial management \& financial performance}

Financial management recognizes that in order to attain the objectives, there must be efficient raising and allocation of resources within the organization. When the relationship between financial management and financial performance is analyzed, it should be noted that there are other factors which account for potential in fluencies on the relationship although these other variables are not directly related to the relationship between $\mathrm{F} / \mathrm{M}$ and $\mathrm{F} / \mathrm{P}$, it is important to take them into account in order to isolate their effect on performance. These variables include degree of risk, firm size and capital intensity and factors such as growth and development. This study held these variables as control variables.

The ultimate goal of financial management is to maximize the financial wealth of the business owners. This general goal can be viewed in terms of more specific objectives: profitability and liquidity. Profitability management is concerned with maintaining or increasing a business' earnings through attention to cost control, inventory management and capital expenditure. Liquidity management that the business obligations (bills, taxes etc.) are paid. McMahon also viewed growth as another objective of financial management in relation to liquidity, growth and profitability.

However, the definition of $\mathrm{F} / \mathrm{M}$ recognizes that in order to obtain the objectives, the shareholders must be concerned with the raising and allocation of resources within the firm, must have a clear focus on what is to be attained and must be willing to commit their investment for a long period of time to realize the firm's objectives or the aims. An efficiently functioning financial sector is a very important determinant to economic development according to Kasekende he asserts that organizations with well-developed financial management systems grow faster and more consistently than those with weaker systems and are able to adjust to economic conditions considering the worldwide experiment shows. Kakuru noted that commitment of funds into long term assets is decided in the role [13]. The allocation of funds finally determines the asset mix of the firm and hence its business. Both the business mix and financing risk have serious implications for the success of the firm. The financial manager who is responsible for those decisions has therefore a very important role in shaping the fortunes of the firm. Organ and Bateman [14] emphasized that performance is the combination of return on shareholders' investment growth in sales and efficient use of resources. Kikonyogo [15] puts it that organizations collapse due to mismanagement of finance thus has now started to cope up with competition by financial management reform.

According to Needham and Dransfield [16] various measures are used to evaluate $\mathrm{F} / \mathrm{P}$ and three main statements have been developed to provide this information that is the profit and loss account, cash flow statement and statement of comprehensive income. Profit and loss account values in monetary terms the transactions of a business over specified period namely one year, statement of financial position shows the financial position of the business at a specified period and cash flow statement shows movement in cash (inflow and outflow of cash). It provides information concerning the nature and value of asset employee in the business, the nature and value of assets employed in the business and value of the liabilities to others and how the business has funded them. A cash flow statement show the ability of the business to generate cash flows and gives users accounts on a fresh insight into equity or profit earned and ability of the business to remain solvent.

However, following the Advisory Services Uganda, the Advisory
Services helps to address concerns and need of the key executives such as the Chief Finance Officer or Chief Compliance Officer as well as the Board and Audit committee both regularity demands and strategic approach to performance and risk management. Our professionals provide organizations with the services that help them to build value within their regulatory environment managing both financial and operational drives of risk. Advanced management accounting (2006), records the relationship between (CEO cooperation and firm performance is a field of intense theoretical and emphatically research. The purpose of this is to gain additional insight into the nature of this relationship by examining emphatically and relatively on explored areas on its non-linearity. The finding of this study show strong evidence that support the view that the relationship between executive compensation and firm performance non-linear and a symmetries.

Kent found out that, objective performance i.e. measures include indicators, such as profit growth, returns on capital employed and revenue growth. Organ and Bateman [14], said performance means the ability of an entity to obtain those ends or purpose that brought it into existence. They defined performance as combination of returns on shareholders' investment, growth in sales and efficient use of resources. Itis relatively old corporate performance measure that was adopted during the early part of this century. Despite its age, it continues as one of today's most popular performance measure part of the reason for its popularity is its simplicity not only is it simple to compute but easily understood by average managers. Verchoor however, mentions other financial measures to include value of long term investment, financial soundness and use of 30 corporate assets. He also talks of non-financial performance measures to include, innovation, ability to attract, develop and keep qualified or talented people, quality management, quality product or services and community and environment responsibilities. Such irregularities are detected by authorities and planning which makes possible repetition of such irregularities in future more difficult. However, 2012 Global journal Inc. (US) stated other methods used to measure F/P that is; profitability, return on capital and liquidity.

However, James [17], believes that many firms low performance is the result of poorly performing assets (Business) how performance from poorly performing assets is often related to strategic errors made in the acquisition process in earlier years. For example, some firms acquire business with unrealistic expectations of achieving energy between acquired assets and their current sets of assets.

A common reason for each error is managerial hubris or over valuation of managerial capability in acquisition process [18]. Frank and Sangster [10], added that financial performance is the level of performance of a business over a specified period of time, expressed in terms of overall profits and losses during that time. Evaluating the financial performance of a business allows decision makers to judge the results of the business strategies and activities in objective monetary terms. According to http:11www.investorwords.com/16429/financial performance, $\mathrm{F} / \mathrm{P}$ refers to the level of performance of a business over a specified period of time, expressed in terms of overall profits and losses during that time. Evaluating performance of a business allows decision makers to judge the results of a business strategy and activities in money terms.

Gitman [19] asserts that F/M is the area of business management, devoted to judicious use of capital and careful selection of sources of capital, in order to enable an organization to move in the direction of reaching its goals. This definition points to certain essential aspects of F/M namely prudent or rational use of capital resource and achieving the goal of the firm. According to Oduware [20], F/M entails planning 
for the future of the business enterprise to ensure a positive cash flow. $\mathrm{F} / \mathrm{M}$ involves planning, organizing, directing and controlling the financial activities such as the procurement and the utilization of funds of the enterprise. From the organizational point of view, the process of $\mathrm{F} / \mathrm{M}$ is associated with financial planning and financial control. Financial planning seeks to quantify various financial resources available and plan the size and timing of expenditures. This study will specifically focus on annual budgets control, financial analysis, internal control and accountability and how they affect performance.

In conclusion, Gebelein [21], stressed that business concern needs finance to meet their requirements in economic world. Any kind of business activity depends on the finance. Hence, it is called lifeblood of business organization. Whether the business concerns are big or small, they need finance to fulfill their activities. The need to enhance effectiveness of the business of the organization lies in the heart of management of the firm, there are several resources to achieve this which include money men and the machine of these resources, and the most important is men.

\section{Methodology}

\section{Research design}

The researcher used descriptive research design to describe the effects of financial management on financial performance of TMC in terms of accountability as it exists at present. It entailed reporting what has happened or what is happening without asking questions. The advantage of this design is that it is easy to understand [22]. The research was also both qualitative in that it entirely involved people's opinions which could not be expressed in numerical terms regarding the study and quantitative in nature which involved testing hypothesis and examining relationships among the two variables. These variables in turn were measured on an instrument so that numbered data can be analyzed using statistical procedures like correlation, standard deviation, mean, mode among others. The research also gave a cross section analysis for indicating the time frame or dimensions that the research took.

Statistically, in order for generalization to take place, a sample of at least 30 elements must exist [23]. Therefore, from the study population of 33 staffs, a sample size of 30 from within each group in proportion that each group bore to the population as a whole was taken using random sampling (used where the population of interest is not homogeneous and can subdivided into groups to obtain a representative sample) and purposive sampling (used when representativeness of the sample is of importance).

\section{Data collection methods and instruments}

This involved a set of questions presented to the respondents for their answers. The questionnaire was used for primary data collection because they are held to be straightforward and less time consuming for both the researcher and the participants [24]. Here, the researcher gave the questionnaires to the treasurer, Cashiers, Revenue officers and the tax collectors of TMC LG, then they were filled, and data was coded, edited and tabulated for easy credibility and analysis. Kothari document review method involved verifying various documents like financial statements, journals, FY budgets, reports, finial accounts, accounting regulations using documentary review checklist and noting down all the relevant information given to the researcher by the respondent [22].

Interview method involves face to face interaction between the respondent and the researcher. This method has a very high degree of accuracy than the questionnaire method and the information in most cases is correct. During the research in the field, the researcher interviewed many people at TMC like the Chief Accountant, and C. A. $\mathrm{O}$ who relate directly to finance at the council using an interview guide.

\section{Presentation, Analysis and Interpretation of the Findings}

\section{Benefits of budgetary management in financial performance}

From the Table 1 above, 30(100\%) of the respondents agreed that budgetary Management helps in resource allocation and formulation of policies in Tororo district local government. And none of the respondents disagreed according to the questionnaires. This implies that budgetary management is of great benefit in terms of resource allocation and formulation of policies so as to enhance financial performance of Tororo district local government as evidenced in the various documents like financial year budgets prepared in the organization to ensure resources are allocated carefully in relation with the available funds thus the finance staff are able to perform basing on the budgets prepared so as to attain organizational goals. This was obtained during documentary review checklist.

Out of the 30 respondents, $26(86.6 \%)$ agreed that budgetary management helps in fixing organizational goals, much as 4(13) \% were not sure while non-disagreed. This implies that uses of budgetary management help in fixing organizational goals so as to ensure funds

\begin{tabular}{|c|c|c|c|c|c|c|c|c|c|c|}
\hline \multirow{3}{*}{\begin{tabular}{|l|} 
Item \\
Benefits of budgetary management \\
\end{tabular}} & \multicolumn{10}{|c|}{ Response } \\
\hline & \multicolumn{5}{|c|}{ Frequency } & \multicolumn{5}{|c|}{ Percentage } \\
\hline & SA & A & NS & $\mathrm{D}$ & SD & SA & A & NS & $\mathrm{D}$ & SD \\
\hline Resource allocation and formulation of policies in TDLG & 15 & 15 & 0 & 0 & 0 & 50 & 50 & 0 & 0 & 0 \\
\hline Fixing Organizational goals in TDLG & 12 & 15 & 3 & 0 & 0 & 40 & 50 & 10 & 0 & 0 \\
\hline $\begin{array}{l}\text { Acts as a tool for measuring performance in terms of accountability } \\
\text { in TDLG }\end{array}$ & 21 & 8 & 1 & 0 & 0 & 70 & 27 & 3 & 0 & 0 \\
\hline Reduces deviation of financial resources in TDLG & 20 & 8 & 2 & 0 & 0 & 67 & 26 & 6 & 0 & 0 \\
\hline Acts as a tool for planning for expenditures in TDLG & 20 & 10 & 0 & 0 & 0 & 67 & 33 & 0 & 0 & 0 \\
\hline $\begin{array}{l}\text { Acts as a tool to correct any deviations in financial resources in } \\
\text { TDLG }\end{array}$ & 20 & 10 & 0 & 0 & 0 & 67 & 33 & 0 & 0 & 0 \\
\hline $\begin{array}{l}\text { Promotes communication since budgets acts as blue prints for } \\
\text { planning in TDLG }\end{array}$ & 15 & 14 & 1 & 0 & 0 & 50 & 47 & 3.3 & 0 & 0 \\
\hline Promotes allocative efficiency and operational efficiency in TDLG & 10 & 5 & 7 & 8 & 0 & 33.3 & 16.6 & 23.3 & 26.6 & 0 \\
\hline
\end{tabular}

Source: Primary data, (2016) 
are spent correctly. This enables the organization to perform effectively and attain its goals.

"Budgetary management ensures that organizational goals are fixed by ensuring that funds are spent on ventures that are productive to the public and unproductive ventures are left out and committing funds to productive ventures aligns and fixes the goals without deviation drawn from the budget, but the organization still faces a problem of deviation of financial resources and hence the organization goals are at times not realized." as noted by one of the officials during interviews.

From table above, 29(96.6\%) of the respondents agreed that efficient budgetary management acts as a tool for measuring performance in TMC LG, and 1(3)\% were not sure and there was none who disagreed. This implies that efficient budgetary management acts as a tool for measuring performance in terms of accountability in that when resources are well allocated, monitored and well evaluated, performance can be measured, and the staff were able to give accountability as indicated by the scorecard initiative where TMC LG's was ranked the best by ACODE during financial year 2014/15.

From table above, 28(93\%) of the respondents agreed that Budgetary management reduces deviations of financial resources in TMC LG and $2(6 \%)$ were not sure. This implies that Budgeting management reduces deviations of financial resources in TMC LG in that funds are distributed and spent according to how they are allocated in the budget and this makes it difficult to deviate from the plan drawn in the budget.

During the interview with one of the accountants, he commented that "budgetary management reduces deviations since funds are spent according to how it was budgeted for by the planning committee however, he further noted that deviation of financial resources still a challenge faced by the organization".

From table above, 30(100\%) of the respondents strongly agreed that Budgetary management acts as a tool for planning for expenditures in TMC LG, and none were not sure, or disagreed. This indicates that budgetary management acts as a tool for planning in that when budgets are drawn; planning for expenditures using the financial resources available becomes simplified in TMC LG leading to proper performance.

From table above, $30(100 \%)$ of the respondents agreed that Budgetary management acts as a tool for planning for expenditures in TMC LG, and none were not sure, or disagreed. This indicates that budgetary management acts as a device to correct any deviations of financial resources in that if expenditures for a given activity exceed the allocated budget at any point of time, it will signal deviation from prescribed sources hence corrections are made thus maintaining proper financial performance in TMC LG. From the table above, 29(96.6\%) of the respondents agreed that efficient budgetary management promotes communication in the organization, and $1(3.3 \%)$ were not sure and there was none who disagreed. This implies that efficient budgetary management acts as a blue print for planning in the organization. Through budgets, people are able to know what the organization is intending achieve in a given financial year period which in turn leads to increased performance.

"Budgets are very important tool drawn by many organizations because of its credible benefits to the organization like communication. After budgets have been drawn, it tells what should be done and the staffs are able to follow so as to attain organizational goals". as noted by one of the staffs during the interviews.

As per the second objective which aimed at establishing the roles of planning on financial performance of TMC LG, the following information was obtained.

From the Table 2 above, $24(80 \%)$ agreed that Planning is aimed at forecasting the future and preparing for it in TMC LG, 6(20\%) were not sure, none of the respondents disagreed. This implies that Planning is aimed at forecasting the future and preparing for it in TMCLG to identify the future needs and changes in the next year to enable the staff of TMC approximate financial requirements and how to raise the necessary financial resources and distribute them effectively to ensure efficient financial performance in the organization. As evidenced by the majority of respondents who gave a positive response towards the question advanced to them with an overall goal in mind. "Planning makes it easy to forecast the future demands of an organization and also various changes" as highlighted during the interviews. In agreement, Lewis [8], through information system emphasized that planning involves selecting objectives and courses of action to achieve them after forecasting future milestone of the organization.

From table above, 29(97\%) of the respondents agreed that Effective planning leads to clear goals and objectives of the organization, 1(3\%) were not sure and none of the respondents disagreed or strongly disagreed to the statement. The finding implies that effective planning enables the organization to set its goals, objectives, and devise ways of achieving them within a given time bound. This is done by ensuring proper financial distribution and performance of financial resources to attain the goals.

From table above, $30(100 \%)$ of the respondents strongly agreed that Effective planning leads to proper monitoring, controlling and evaluation of financial resources in TMC LG, none of the respondents were not sure or disagreed.

The above findings implies that effective planning ensures that cost effective program implementation within a system of accountability,

\begin{tabular}{|c|c|c|c|c|c|c|c|c|c|c|}
\hline \multirow{3}{*}{$\begin{array}{l}\text { Item } \\
\text { Roles of planning on financial performance }\end{array}$} & \multicolumn{10}{|c|}{ Response } \\
\hline & \multicolumn{5}{|c|}{ Frequency } & \multicolumn{5}{|c|}{ Percentage } \\
\hline & SA & A & NS & $\mathrm{D}$ & SD & SA & A & NS & $\mathrm{D}$ & SD \\
\hline Forecasting the future and preparing for it in TMC LG & 10 & 14 & 6 & 0 & 0 & 33 & 47 & 20 & 0 & 0 \\
\hline Clear goals and objectives of the organization & 24 & 5 & 1 & 0 & 0 & 80 & 17 & 3 & 0 & 0 \\
\hline Implemented through preparing budgets in TMC LG & 28 & 2 & 0 & 0 & 0 & 93 & 7 & 0 & 0 & 0 \\
\hline $\begin{array}{l}\text { Monitoring, controlling and evaluation of financial resources in TMC } \\
\text { LG }\end{array}$ & 25 & 5 & 0 & 0 & 0 & 83 & 17 & 20 & 0 & 0 \\
\hline Set targets to be achieved within a time bound in TMC LG & 16 & 8 & 6 & 0 & 0 & 53 & 27 & 0 & 0 & 0 \\
\hline Efficient distribution of financial resources in TMC LG & 20 & 10 & 0 & 0 & 0 & 67 & 33 & 0 & 0 & 0 \\
\hline
\end{tabular}

Source: Primary data (2016)

Table 2: Findings on roles of planning 
ensures that expected results are achieved and maintains stability of financial resources for effective performance of financial resources in TMC LG as shown by the responses from the respondents above.

From table above, $30(100 \%)$ of the respondents strongly agreed that Planning is implemented through preparing budgets in TMC LG, there were no respondents who were not sure or those who disagreed.

This implies budgets leads to refinement of plans for instance during planning, budgets are drawn to ensure resources are allocated effectively to various areas of development to ensure proper financial performance.

From table above, $30(100 \%)$ respondents agreed that Planning helps to set targets to be achieved within a time bound in TMC LG, none of the respondents were not sure or had respondents. This implies that Planning helps to tell when, what and how something is to be done within a time bound in TMC LG in order to carryout proper financial management and it is also necessary to formulate a fully coordinated detailed plan in both financial and quantitative terms, as shown in the table above.

\section{Findings on the relationship between financial management and financial}

Performance using Pearson correlation: This section focuses on establishing the relationship that exists between financial management and financial performance of TMC LG. It looks at financial management as independent variable while financial performance was a dependent variable. The findings of the section are summarized in the following Table 3.

Out of the 30 respondents, $22(73.3 \%)$ agreed, $8(26.6 \%)$ were not sure that strong financial management systems leads to improved performance. However, during the interview, the senior Accountant highlighted that "strong financial management through planning and budgeting leads to improved performance in the organization". This implies that TMC LG must have a strong financial management system with a clear focus on what is to be attained within a time bound through planning, budgeting and then commit the financial resources to ensure improved financial performance in order to realize the organizational goals. As evidenced by the majority of the respondents who strongly agreed and agreed to the statement. James [17], believes that many firms with low performance are as a result of poor financial management systems.

Out of the 30 respondents, $26(86.6 \%)$ agreed, $4(13.3 \%)$ were not sure that financial management is concerned with raising and allocation of financial resources. "Financial management is mainly concerned with raising and allocation of financial resources. In TMC, funds are raised through taxes, grants from the government among others and then allocated to various areas of development through budgets". The senior Accountant TMC highlighted during the interview. This implies that the various sources funds like taxes, grants among others are very vital in performance of TMC LG. By using budgets, these funds are evenly distributed leading to good financial performance. From table above, $24(80 \%)$ of the respondents agreed, $6(20 \%)$ were not sure, that financial performance is as a result of efficiently functioning financial sector. This implies that for an organization with well-developed financial management systems grow faster and consistently in terms of financial performance as shown by the majority of the respondents who strongly agreed and agreed to the statement.

Out of the 30 respondents, $24(80 \%)$ agreed, 6(20\%) were not sure that budgeting helps to improve financial performance in TMC LG. This implies that budgeting as a financial management tool is drawn to facilitate the allocation of financial resources and monthly, quarterly reports are normally drawn to show weather the organization is performing as per the budget or not so as to ensure financial performance in the organization.

Out of the 30 respondents, $23(76.6 \%)$ agreed, 5(16.6\%) were not sure while 2(6.6\%) disagreed that efficient financial management helps in controlling expenditures in TMC LG. This implies that financial management that helps to control expenditures in organizations through budgets as shown in the documentary review checklist.

However, the researcher used spearman's rank correlation to determine the relationship between variables. The agreed responses were taken to be $\mathrm{x}$-values and not sure were taken to be y-values (Table 4).

Spearman rank $(\mathrm{r})=1-\left(6 \sum \mathrm{d} 2 /(\mathrm{n} 2-1)\right)$

Where; d-difference between the two ranks, n-Number of elements, 6-constant

$$
\begin{aligned}
& =1-\left(6^{\star} 18.5 / 5(52-1)\right) \\
& =1-(111 / 120) \\
& =1-0.925 \\
& =0.9075 \\
& =0.91
\end{aligned}
$$

From the findings, there is a strong positive relationship between financial management and financial performance where $r=0.91$, $\mathrm{p}<0.05$. From the above table, the correlation coefficient between financial management and financial performance is positive that is 0.91

\begin{tabular}{|c|c|c|c|c|c|c|c|c|c|c|}
\hline \multirow{3}{*}{ Item } & \multicolumn{10}{|c|}{ Response } \\
\hline & \multicolumn{5}{|c|}{ Frequency } & \multicolumn{5}{|c|}{ Percentage } \\
\hline & SA & A & NS & D & SD & SA & A & NS & $\mathrm{D}$ & SD \\
\hline Strong financial management system leads to improved performance in TDLG & 12 & 10 & 8 & 0 & 0 & 40 & 33.3 & 26.6 & 0 & 0 \\
\hline $\begin{array}{l}\text { Financial management is concerned with raising and allocation of financial } \\
\text { resources in TDLG }\end{array}$ & 16 & 10 & 4 & 0 & 0 & 53.3 & 33.3 & 13.3 & 0 & 0 \\
\hline Financial performances is as a result of efficiently functioning financial sector & 11 & 13 & 6 & 0 & 0 & 40 & 43.3 & 20 & 0 & 0 \\
\hline Budgeting helps to improve financial performance & 14 & 10 & 6 & 0 & 0 & 55 & 33.3 & 20 & 0 & 0 \\
\hline Efficient financial management helps in controlling expenditures in TDLG & 12 & 11 & 5 & 2 & 0 & 40 & 36.6 & 16.6 & 6.6 & 0 \\
\hline
\end{tabular}
which means that an increase in financial management also leads to an increase in the level of financial performance and a decrease in financial management levels also leads to a decrease in the level of financial performance.

Source: Primary data (2016)

Table 3: Showing findings on the relationship between financial management and financial performance. 


\begin{tabular}{|c|c|c|c|c|c|}
\hline \multicolumn{2}{|c|}{ Responses } & \multicolumn{4}{|c|}{ Ranking } \\
\hline Agree $(\mathrm{x})$ & Not sure $(\mathrm{y})$ & $\mathrm{R}_{\mathrm{x}}$ & $\mathrm{R}_{\mathrm{Y}}$ & $\mathrm{d}=\mathrm{R}_{\mathrm{X}}-\mathrm{R}_{\mathrm{Y}}$ & $\mathrm{d}^{2}$ \\
\hline 10 & 8 & 4 & 1 & 3 & 9 \\
\hline 10 & 4 & 4 & 5 & -1 & 1 \\
\hline 13 & 6 & 1 & 2.5 & -1.5 & 2.25 \\
\hline 10 & 6 & 4 & 2.5 & 1.5 & 2.25 \\
\hline 11 & 5 & 2 & 4 & -2 & 4 \\
\hline & & & & & 18.5 \\
\hline
\end{tabular}

Source: Primary data (2016)

Table 4: Showing spearman's rank correlation.

\section{Discussions, summary of findings, conclusion, recommendations and areas of further research}

Benefits of budgetary management: According to Table 1, the findings reveal that $30(100 \%)$ of the respondents agreed that budgetary Management helps in resource allocation and formulation of policies in Tororo district local government, according to the findings in the questionnaires and this was in line with the interviews. This implies that budgetary management is of great benefit to Tororo district local government as evidenced in the various documents like financial year budgets prepared in the organization to ensure resources are allocated carefully in relation with the available funds thus the finance staff are able to perform basing on the budgets prepared so as to attain efficient financial performance with organizational goals in mind. In agreement with the above findings, Modarrasi noted that budgets occupy a leading place among the tools of financial management employed to direct and control the financial affairs of the organization. Premchand also noted that budgetary management stipulates which activities and programs should be actively pursued, emphasized or ignored in the period under scope, considering the limited financial resources available to the organization.

Out of the 30 respondents, the findings revealed that 26(86.6\%) agreed that budgetary management helps in fixing organizational goals, 4(13) \% were not sure basing on the questionnaires. However according to the interviews, this is still a challenge due to deviation and limited financial resources thus organizational goals are at times not realized according to the time bound. This implies that though use of budgetary management helps to direct monitor and control the organization's activities so as to ensure funds are spent correctly, TMC LG still faces a challenge of deviation in financial resources. This makes the organization not to attain its goals with a given time bound. However, Scarlett [4], highlighted that budgetary management as a principle, procedures and practices helps in fixing organizational goals and this requires three important objectives like maintenance of fiscal discipline, attaining allocative efficiency and operational efficiency.

From same Table above, the findings further revealed that 29(96.6\%) of the respondents agreed that efficient budgetary management leads to acts as a tool for measuring performance in terms of accountability in TMC LG, and 1(3)\% were not sure, $0 \%$ disagreed. This implies that efficient budgetary management acts as a tool for measuring performance in terms of accountability in that when resources are well allocated, monitored and well evaluated, performance also increases in specific time aims, and the staff are able to give accountability as indicated by the scorecard initiative where TMC LG's was ranked the best by ACODE during financial year 2014/15. This finding is in agreement with what Premchand noted that budgetary management stipulates which activities and programs should be actively pursued, emphasized or ignored in the period under scope, considering the limited financial resources available to the organization
In addition, Table 1 above indicates that 28(93.3\%) of the respondents strongly agreed that Budgetary management reduces deviations of financial resources in TMC LG, and 2(6\%) were not sure. This implies that budgetary management reduces deviations of financial resources in TMC LG in that funds are distributed and spent according to how they are allocated in the budget and this makes it difficult to deviate from the plan drawn in the budget. During the interview with one of the chief accountant, he commented that "budgetary management reduces deviations since funds are spent according to how it was budgeted for by the planning committee however, he further noted that deviation of financial resources still a challenge faced by the organization". In agreement to the findings, Otley [7], noted that if the expenditures for a given activity exceed the allocated budget at any point in time, it will signal deviation from prescribed course thus requiring attention hence maintaining proper financial performance.

Findings in Table 1 above further shows that 20(67\%) of the respondents strongly agreed that Budgetary management acts as a tool for planning for expenditures in TMC LG, 10(33\%) agreed, this indicates that budgetary management acts as a tool for planning in that when budgets are drawn; planning for expenditures using the financial resources available becomes simplified in TMC LG leading to proper performance. Premchand also agreed with this finding and noted that budgetary management is tool for planning for expenditures because it stipulates which activities and programs should be actively pursued, emphasized or ignored in the period under scope considering the limited financial resources available and Morgan and Malcolm also asserted that budgetary management allows planning for expenditures thus facilitating systematic spending and allocation of financial resources [6].

Furthermore, Table 1 reveals that 20(67\%) of the respondents strongly agreed that Budgetary management acts as a tool for planning for expenditures in TMC LG, 10(33\%) agreed, and none were not sure, or disagreed. This indicates that budgetary management acts as a device to correct any deviations of financial resources in that if expenditures for a given activity exceed the allocated budget at any point of time, it will signal deviation from prescribed sources hence corrections are made thus maintaining proper financial performance in TMC LG. This finding is in agreement with what Otley noted concerning budgetary management being a devise to correct any deviations with an aim of maintaining proper financial performance [7].

More still, Table 1 above indicates that 15(50\%) of the respondents strongly agreed that efficient budgetary management promotes communication in the organization, $14(46.6 \%)$ agreed, and $1(3.3 \%)$ were not sure and there was none who disagreed. This implies that efficient budgetary management acts as a blue print for planning in the organization. Through budgets, people are able to know what the organization is intending achieve in a given financial year period which in turn leads to increased performance. "Budgets are very important tool drawn by many organizations because of its credible benefits to the organization like communication. After budgets have been drawn, it tells what should be done and the staffs are able to follow so as to attain organizational goals" one of the respondents highlighted during the interview. In support of the statement, Otley [7], noted that budgetary control promotes communication because budgets acts as a blue print for organization's plans of operation and can only be coordinated through communications at all levels so as to reduce failure and misunderstandings through transparency in the organization. 


\section{Roles of planning in financial performance}

From Table 2 above, 10(33\%) strongly agreed that Planning is aimed at forecasting the future and preparing for it in TMC LG, $14(47 \%)$ agreed, 6(20\%) were not sure, none of the respondents disagreed. This implies that Planning is aimed at forecasting the future and preparing for it in TMC LG to identify the future needs and changes in the next year to enable the staff of TMC approximate financial requirements and how to raise the necessary financial resources and distribute them effectively to ensure efficient financial performance in the organization. As evidenced by the majority of respondents who gave a positive response towards the question advanced to them as which is in line with interview "Planning makes it easy to forecast the future demands of an organization and also various changes", one of the respondent remarked. Lewis in agreement noted through information system that planning as part of management function helps in forecasting future milestone and preparing for it which leads to efficiency in performance of financial resources [8].

Furthermore, Table 2 above reveal that 29(96.6\%) of the respondents agreed that Effective planning leads to clear goals and objectives of the organization, $1(3 \%)$ were not sure and none of the respondents disagreed or strongly disagreed to the statement. The above finding implies that effective planning enables the organization to set its goals, objectives, and devise ways of achieving them within a given time bound. This is done by ensuring proper financial distribution and performance of financial resources to attain the goals. Bhatia highlighted that sound planning is characterized by clear objectives and goals. It must be simple and well balanced, flexible so as to accept any changes in the resources and should be in time bound which is in support of what the questionnaires and interviews reveal.

In addition, Table 2 above show that $25(83 \%)$ of the respondents strongly agreed that Effective planning leads to proper monitoring, controlling and evaluation of financial resources in TMC LG, 5(17\%) agreed, none of the respondents were not sure, disagreed and strongly disagreed. The above findings implies that effective planning ensures that cost effective program implementation within a system of accountability, ensures that expected results are achieved and maintains stability of financial resources for effective performance of financial resources in TDLG as shown by the responses from the respondents above. In agreement, Carr urges that monitoring and evaluation of planned activities is necessary because it maintains stability in the organization [9]. This is achieved by drawing the technical plans and five years plans in the organization.

From Table 2 above, 28(93\%) of the respondents strongly agreed that Planning is implemented through preparing budgets in TMC LG, $2(7 \%)$ agreed, there were no respondents who were not sure or those who disagreed. This implies budgets leads to refinement of plans for instance during planning, budgets are drawn to ensure resources are allocated effectively to various areas of development to ensure proper financial performance. Frank and Sangster noted that budgets are put in place in advance based on the anticipated set of circumstances or environment and the major decisions are made based on these planned budgets [10]. This is in agreement with the findings above.

More still, Table 2 above reveal that 20(67\%) respondents strongly agreed that Planning helps to set targets to be achieved within a time bound in TMC LG, 10(33\%) agreed, none of the respondents were not sure or had respondents. This implies that Planning helps to tell when, what and how something is to be done within a time bound in TMC LG in order to carryout proper financial management and it is also necessary to formulate a fully coordinated detailed plan in both financial and quantitative terms, as shown in the table above. As highlighted by Briston through information system emphasizes that planning involves selecting objectives and courses of action to achieve them having set the target to be achieved.

\section{Relationship between financial management and financial performance}

From the findings in Table 3, the researcher used spear man's rank correlation to determine the relationship between the two variables as shown in Table 4. From the findings, there is a strong positive relationship between financial management and financial performance where $r=0.91, p<0.05$. The correlation coefficient between financial management and financial performance is positive that is 0.91 which means that an increase in financial management also leads to an increase in the level of financial performance and a decrease in financial management levels also leads to a decrease in the level of financial performance. This is in agreement with James who noted that increased level of financial performance is as a result of sound management systems in a firm thus creating a positive business model that continues to grow and reap great financial motives [17].

\section{Conclusion}

The study sought to establish the effects of financial management on financial performance of TMC LG. Following the research findings made and discussions carried out, the researcher had to arrive at the following conclusions.

TMC LG has done a very great deal in the struggle to improve financial performance through recognizing the benefits of budgetary management in the organization such as resource allocation and formulation of policies, fixing organizational goals, tool for planning for expenditures among others. TMC LG has also taken note of the roles of planning on financial performance such as forecasting the future and preparing for it, setting clear goals and objectives among others in order to improve financial performance of TMC LG. All these when well-planned and conducted in TMC LG; show that financial management has an effect on the level of financial performance and thus indicating a positive relationship of 0.91 between the two variables. 91 which means that an increase in financial management also leads to an increase in the level of financial performance and a decrease in financial management levels also leads to a decrease in the level of financial performance. This is in agreement with James who noted that increased level of financial performance is as a result of sound management systems in a firm thus creating a positive business model that continues to grow and reap great financial motives [17].

\section{Recommendations}

The study recommended that TMC LG should maintain its budgetary management systems since it is of great benefit to the organization as evidenced by the majority of respondents who agreed. This will help to improve on service delivery and accountability and hence improve on performance since budgets stipulates which activities and programs should be actively pursued, emphasized or ignored in the period under scope.

The study also recommended that the management of TMC LG should frequently revisit their budget activities to ensure that there is no deviation from the budget and expenditures are in accordance with the budget among others. This will improve on service delivery and accountability in the organization. 
Citation: Mutya T, Josephine A (2018) Financial Management a Wheel to Financial Performance of Local Governments in Uganda: A Case Study of Tororo Municipal Council. J Bus Fin Aff 7: 330. doi: 10.4172/2167-0234.1000330

Page 10 of 10

On the role of planning, the study recommends that the organization should take up planning as the overall part of management function because of its tremendous roles like forecasting the future and preparing for it, helps in proper monitoring, controlling and evaluation of financial resources among others as evidenced by the large percentage of respondents who agreed to the statement. Therefore, it should be taken as a serious tool in LG which aides in attainment of organizational goals.

TMC LG should also focus on other departments in the organization since other than finance

\section{Areas of Further Research}

The study suggests that further research to be done on the effects of computerized system of financial management on financial performance.

The study suggests that further research should be carried out on the challenges to financial management and in other areas such as different departments since they are always faced with challenges.

The study also suggests further research on the roles of internal controls in financial performance. The study also suggests further research on the benefits of financial tracking and analysis in TMC LG.

The study also recommends that further research should be done on the relationship between gender and financial performance of the organization.

\section{References}

1. Shah A (2009) Budgeting and budgetary institutions. World bank publications.

2. Waddell S (2000) Complementary resources: The win-win rationale for partnerships with Ngos. Bendell, Greenleaf publishing Sheffield.

3. Hohler A (2005) Improving accountability: Control and command. Real finance journal, pp: 43-49.

4. Scarlett R (2008) Official learning system. CIMA Publishers, Oxford.

5. Preetabh (2010) Advantages of budgetary control.
6. Morgan E, Malcolm P (2005) Financial management and control in higher education. New York.

7. Otley S (2001) Budget use and management performance. J Account Res 16 122-149.

8. Lewis D (1996) Financial management and policy. Prentice Hall, New Delhi.

9. Carr JJ (2000) Requirements of engineering and management: The key to designing complex systems. The TQM magazine 12: 400-407.

10. Frank W, Sangster A (2007) Business accounting. (10th edn). Prentice Hall New Delhi.

11. Selznick P (1988) Foundations of the theory of organization. American sociology review 13: 25-35.

12. Atkinson RK (2004) Management accounting. (4th edn), Prentice Hall, New Delhi.

13. Kakuru J (2007) Finance Decisions and the Business. Fountain Publishers, Kampala.

14. Organ DW, Bateman TS (1991) Organization Behavior. RR Donnelley and Sons Company, USA.

15. Kikonyogo CN (2000) Recent economic development: The Uganda financial sector.

16. Needham D, Dransfield R (2010) Business studies international GCSE. Nottingham Trent University.

17. James C (1992) Introduction to financial management. Irwin Homewood publishers, USA.

18. Gupta PP (2008) Social sector policy review. International Journal of Disclosure and Governance.

19. Gitman LJ (2007) Principle of managerial finance. Addison Wesley, New York.

20. Oduware $U$ (2011) Overview of F/M.

21. Gebelein S (2006) Talent management. Minnesota Business Magazine.

22. Kothari CR (2010) Research methodology: Methods and techniques. (2nd edn), New Age International Publishers, New Delhi.

23. Cooper R, Schinder S (2003) Business research methods. (8th edn), Tata McGraw Hill, New Delhi.

24. Owens LK (2002) Introduction to survey research design. 